\title{
Biochar Alteration of the Sorption of Substrates and Products in Soil Enzyme Assays
}

\author{
Mark Swaine, ${ }^{1,2}$ Rachel Obrike, ${ }^{1,3}$ Joanna M. Clark, ${ }^{1}$ and Liz J. Shaw ${ }^{1}$ \\ ${ }^{1}$ Soil Research Centre, Department of Geography and Environmental Science, University of Reading, Reading RG6 6DW, UK \\ ${ }^{2}$ SRUC, Crop and Soil Systems Research Group, West Mains Road, Edinburgh EH9 3JG, UK \\ ${ }^{3}$ Reading Scientific Services Ltd., Reading Science Centre, University of Reading, Reading RG6 6LA, UK \\ Correspondence should be addressed to Liz J. Shaw; e.j.shaw@reading.ac.uk
}

Received 3 July 2013; Accepted 14 August 2013

Academic Editor: Robert L. Bradley

Copyright (C) 2013 Mark Swaine et al. This is an open access article distributed under the Creative Commons Attribution License, which permits unrestricted use, distribution, and reproduction in any medium, provided the original work is properly cited.

\begin{abstract}
Pine wood and barley straw biochar amendments to Kettering and Cameroon sandy silt loam soils (15, 30, or $150 \mathrm{mg} \mathrm{biochar} \mathrm{g}^{-1}$ soil) caused significant reductions (up to $80 \%, P<0.05$ ) in concentrations of substrate and extractable product in soil dehydrogenase and phosphomonoesterase enzyme assays. Likely this was caused by increased solid-phase sorption of the chemicals in the presence of the biochars under assay conditions. The relationship between assay chemical sorption and biochar concentration depended on the chemical, soil type, biochar type, and their interactions; hence, no uniform correction factor could be derived. This biochar impact on assay constituents will limit the identification of genuine biochar effects on soil enzymes. It is recommended that the assumption of saturating substrate concentrations be checked and that product standards be matrix-matched when conducting enzyme assays with biochar-amended soil.
\end{abstract}

\section{Introduction}

Soil extracellular and intracellular enzymes are the catalysts of organic matter decomposition. Understanding the effect of biochar on the activity of these key enzymes has been identified as a research priority [1]. Soil enzyme activity is typically quantified using assays of the potential activity, where artificial substrates are added at saturating concentrations and undergo enzyme-catalysed transformation to form coloured or fluorescent products [2]. As biochars have been shown to possess a high sorptive affinity for organic chemicals (e.g., [3]), this raises the question of whether biochar might sorb both (i) the organic chemicals added as artificial substrates and (ii) the products in soil enzyme assays. Some studies have considered this possibility [4-6] but the effect of biochar on the behaviour of both the products and substrates used in enzyme assays has not yet been systematically or explicitly quantified under assay conditions. This information is needed if the effects of biochar on soil function are to be correctly identified. Therefore, we examined the effect of biochar addition to soil on (a) the concentration of assay substrate under assay conditions and (b) the extractability of assay product for two enzyme assays that are commonly used to characterize soil quality: the p-nitrophenyl phosphate (pNPP)-based phosphatase assay [7] and the iodonitrotetrazolium chloride (INT)-based dehydrogenase assay $[8,9]$.

\section{Materials and Methods}

2.1. Soil and Biochar. Experiments were conducted using two soil types (Kettering sandy silt loam (total C $=1.8 \%, \mathrm{pH} 7.3$ ) and Cameroon sandy silt loam (total $\mathrm{C}=1.3 \%, \mathrm{pH} 5.4$ )) and biochar made from two feedstocks (pine wood shavings and barley straw; Figure 1). The biochars were produced by heating $\left(500^{\circ} \mathrm{C}, 1\right.$ hour $)$ the respective feedstocks in a muffle furnace in a sealed metal container (volume $=325 \mathrm{~mL}$ ) with a $2 \mathrm{~mm}$ diameter vent hole. Both biochars were then passed through a $1 \mathrm{~mm}$ sieve prior to use. The biochars had the following properties: pine wood shavings-total C $=81 \%$, BET surface area $7.54 \pm 1.1 \mathrm{~m}^{2} \mathrm{~g}^{-1}$; barley straw-total $\mathrm{C}=$ $67 \%$; BET surface area not detectable.

Biochar concentration treatments were established by mixing soil $(<2 \mathrm{~mm})$ with biochar $(<1 \mathrm{~mm})$ on an individual 


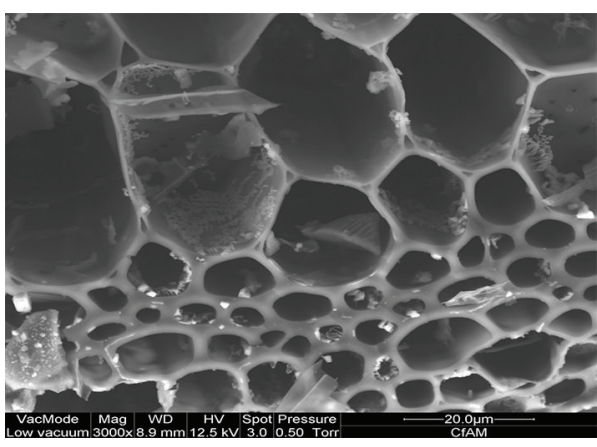

(a)

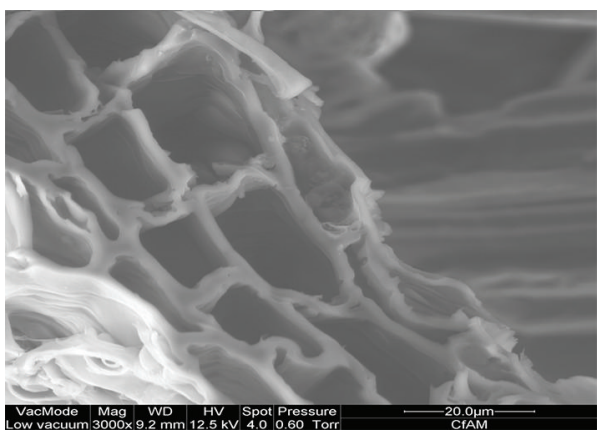

(c)

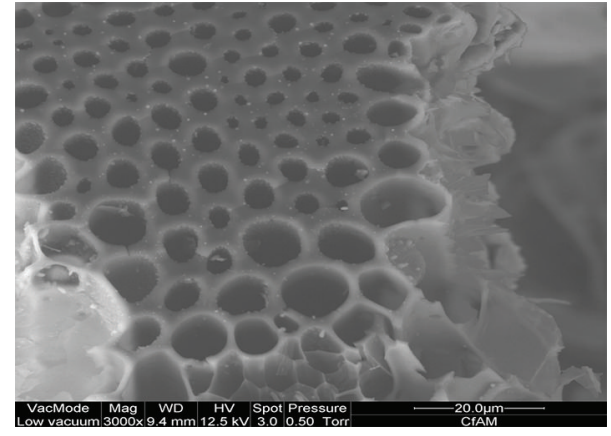

(b)

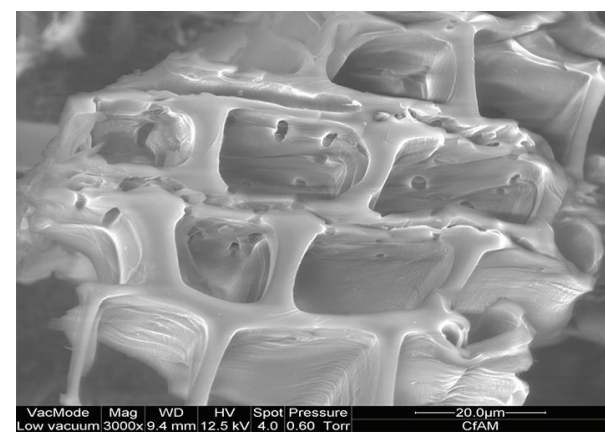

(d)

FIGURE 1: Environmental scanning electron microscope (FEI Quanta FEG 600) images of (a)-(b) barley straw biochar and, (c)-(d) pine wood shaving biochar. Images are 3000x magnification and were obtained at $12.5 \mathrm{kV}$ and low vacuum $(0.50$ and 0.60 Torr for straw and pine wood biochars, resp.).

TABLE 1: Effect of biochar concentration and biochar feedstock on soil $\mathrm{pH}_{\text {water }}$ and cation exchange capacity $\left(\mathrm{CEC}\right.$; cmol Kg${ }^{-1}$ soil) of Kettering and Cameroon soils. Data are mean $\pm \operatorname{SEM}(n=3)$ and $P$ values are derived from one-way ANOVA with biochar concentration as the factor. Mean values within each soil and biochar type combination sharing the same letter are not significantly different $(P>0.05)$.

\begin{tabular}{|c|c|c|c|c|}
\hline \multirow{2}{*}{ Biochar conc. $\left(\mathrm{mg} \mathrm{g}^{-1}\right)$} & \multicolumn{2}{|c|}{$\mathrm{pH}$} & \multicolumn{2}{|c|}{ CEC } \\
\hline & Kettering soil & Cameroon soil & Kettering soil & Cameroon soil \\
\hline \multicolumn{5}{|l|}{ Pine wood biochar } \\
\hline 0 & $7.3 \pm 0.2$ & $5.4 \pm 0.1$ & $14.9 \pm 0.3$ & $8.4 \pm 0.2^{\mathrm{b}}$ \\
\hline 15 & $7.5 \pm 0.1$ & $5.4 \pm 0.1$ & $14.9 \pm 0.8$ & $9.3 \pm 0.3^{\mathrm{ab}}$ \\
\hline 30 & $7.4 \pm 0.2$ & $5.5 \pm 0.1$ & $14.5 \pm 0.2$ & $8.7 \pm 0.7^{\mathrm{b}}$ \\
\hline 150 & $7.5 \pm 0.3$ & $5.4 \pm 0.1$ & $15.4 \pm 0.6$ & $10.1 \pm 0.6^{\mathrm{a}}$ \\
\hline$P$ value & 0.54 & 0.56 & 0.25 & 0.015 \\
\hline \multicolumn{5}{|l|}{ Straw biochar } \\
\hline 0 & $7.3 \pm 0.2^{c}$ & $5.4 \pm 0.1^{\mathrm{d}}$ & $14.9 \pm 0.3^{b}$ & $8.4 \pm 0.2^{\mathrm{C}}$ \\
\hline 15 & $8.4 \pm 0.2^{\mathrm{b}}$ & $6.6 \pm 0.2^{c}$ & $15.6 \pm 0.3^{\mathrm{ab}}$ & $8.1 \pm 0.8^{\mathrm{c}}$ \\
\hline 30 & $8.5 \pm 0.5^{\mathrm{b}}$ & $7.4 \pm 0.3^{b}$ & $16.1 \pm 0.7^{\mathrm{a}}$ & $9.6 \pm 0.4^{\mathrm{b}}$ \\
\hline 150 & $9.6 \pm 0.1^{\mathrm{a}}$ & $8.5 \pm 0.4^{\mathrm{a}}$ & $14.8 \pm 0.5^{\mathrm{b}}$ & $11.7 \pm 0.3^{\mathrm{a}}$ \\
\hline$P$ value & $<0.001$ & $<0.001$ & 0.02 & $<0.001$ \\
\hline
\end{tabular}

sample basis to produce a concentration range of $0,15,30$, or $150 \mathrm{mg}$ dry biochar $\mathrm{g}^{-1}$ dry soil. The resulting $\mathrm{pH}$ and cation exchange capacities of the soil-biochar mixtures are given in Table 1.

2.2. Biochar Effects on Concentrations of Assay Substrates and Products. The effects of biochar feedstock and concentration on assay substrates ( $\mathrm{pNPP}$ and INT) and respective products (p-nitrophenol ( $\mathrm{pNP}$ ) and iodonitrotetrazolium formazan (INTF)) were determined by performing substrate incubations and product extractions based on published assay protocols $[7,8]$.

Specifically, to determine the effect of biochar addition on the concentration of the phosphatase assay substrate (pNPP), samples (1 g dry weight) from each biochar type and concentration treatment $(n=4)$, suspended in modified 
TABLE 2: Statistical evaluation of the effects of soil type, biochar concentration, and biochar feedstock and their interactions on the aqueousphase concentration or extractability of enzyme assay substrates and products, respectively, used in soil dehydrogenase and phosphatase assays. The ANOVA was conducted using general linear model (Minitab 16) with ranked data $(n=4)$.

\begin{tabular}{|c|c|c|c|c|c|}
\hline \multirow[b]{2}{*}{ Source } & \multirow[b]{2}{*}{$\mathrm{DF}$} & \multicolumn{2}{|c|}{ Phosphatase } & \multicolumn{2}{|c|}{ Dehydrogenase } \\
\hline & & $\begin{array}{l}\text { Substrate } \\
\text { p-nitrophenyl phosphate }\end{array}$ & $\begin{array}{l}\text { Product } \\
\text { p-nitrophenol }\end{array}$ & $\begin{array}{l}\text { Substrate } \\
\text { Iodonitrotetrazolium } \\
\text { chloride } \\
\text { alue }\end{array}$ & $\begin{array}{l}\text { Product } \\
\text { Iodonitro-tetrazolium } \\
\text { formazan }\end{array}$ \\
\hline $\begin{array}{l}\text { Soil type (Kettering } \\
\text { loam; Cameroon Oxisol) }\end{array}$ & 1 & $<0.001$ & $<0.001$ & $<0.001$ & 0.088 \\
\hline $\begin{array}{l}\text { Biochar feedstock } \\
\text { (straw; pinewood } \\
\text { shavings) }\end{array}$ & 1 & 0.002 & 0.016 & 0.024 & $<0.001$ \\
\hline $\begin{array}{l}\text { Biochar concentration } \\
\left(0,15,30,150 \mathrm{mg} \mathrm{g}^{-1}\right)\end{array}$ & 3 & $<0.001$ & $<0.001$ & $<0.001$ & $<0.001$ \\
\hline Soil $*$ feedstock $*$ conc & 3 & 0.339 & 0.037 & 0.261 & 0.003 \\
\hline Soil $*$ feedstock & 1 & 0.115 & 0.002 & 0.004 & $<0.001$ \\
\hline Soil $*$ conc. & 3 & 0.014 & 0.474 & 0.013 & 0.013 \\
\hline Feedstock $*$ conc. & 3 & 0.270 & 0.331 & 0.003 & $<0.001$ \\
\hline Error & 48 & & & & \\
\hline Total & 63 & & & & \\
\hline
\end{tabular}

universal buffer (MUB, $4 \mathrm{~mL}$ ) and toluene $(0.25 \mathrm{~mL})$, were amended with pNPP solution $(1 \mathrm{~mL}, 23 \mathrm{mM})$ and incubated $\left(37^{\circ} \mathrm{C}, 1 \mathrm{~h}\right)$. After incubation, soil was removed by centrifugation $(13,000 \times \mathrm{g} ; 5 \mathrm{~min})$ and the pNPP concentration in the supernatant was determined using a spectrophotometer $(400 \mathrm{~nm})$ after conversion to p-nitrophenol using a commercial phosphatase (see Supplementary Material available online at http://dx.doi.org/10.1155/2013/968682). To determine the effect of biochar on the dehydrogenase assay substrate (INT), soil samples ( $1 \mathrm{~g})$ were amended with INT solution $\left(4 \mathrm{~mL}, 20 \mathrm{mg} \mathrm{mL}^{-1}\right)$ and incubated $\left(26^{\circ} \mathrm{C}, 24 \mathrm{~h}\right)$ before centrifugation and determination of INT concentration in the supernatant by spectrophotometry at $248 \mathrm{~nm}$. Blanks receiving $\mathrm{d} \cdot \mathrm{H}_{2} \mathrm{O}$ instead of substrate solution were included for both pNPP and INT tests and all soil samples for substrate tests were autoclaved $\left(20 \mathrm{~min}, 121^{\circ} \mathrm{C}\right.$ on three consecutive days) to eliminate loss of substrate during the incubation due to enzymatic conversion.

To quantify the effect of biochar on the extractability of enzyme assay products (pNP and INTF), samples $(1 \mathrm{~g})$ were amended with either $4 \mathrm{~mL}$ of MUB and $0.25 \mathrm{~mL}$ toluene (pNP test) or $4 \mathrm{~mL} \mathrm{~d} \cdot \mathrm{H}_{2} \mathrm{O}$ (INTF test) and subsequently spiked with a solution of either $\mathrm{pNP}\left(1 \mathrm{~mL}, 10 \mu \mathrm{g} \mathrm{mL}^{-1}\right.$ in MUB) or INTF $\left(0.28 \mathrm{~mL}, 500 \mu \mathrm{g} \mathrm{mL}^{-1}\right.$ in N,N-dimethylformamide) one hour prior to extraction. pNP tests were extracted with $\mathrm{CaCl}_{2}(1 \mathrm{~mL}, 0.5 \mathrm{M})$ and $\mathrm{NaOH}(4 \mathrm{~mL}, 0.5 \mathrm{M})$ whereas the extractant for INTF tests was N,N-dimethylformamide : ethanol $(1: 1, \mathrm{v} / \mathrm{v}, 10 \mathrm{~mL})$. The concentration of extracted product was determined spectrophotometrically at $400 \mathrm{~nm}$ or $464 \mathrm{~nm}$ for pNP and INTF, respectively.

\section{Results and Discussion}

Biochar concentration had a significant effect on concentrations of assay substrates and products in both soils (Table 2), with decreased substrates and products in biochar-amended soil when compared to the nonbiochar-amended $\left(0 \mathrm{mg} \mathrm{g}^{-1}\right)$ control (Figure 2). This suggests that biochar amendment increased the solid-phase sorption of the assay chemicals either by acting as a sorbent itself or altering the strength of sorbate interactions with native soil components (e.g., organic material and clay minerals) through indirect effects on soil chemistry (predominantly modifying soil $\mathrm{pH}$ ). We believe the former to be the most likely explanation for the behaviour of pNP and pNPP given the buffered assay conditions ( $\mathrm{pH}$ 6.5) and the strong alkaline extraction $(0.5 \mathrm{M}$ $\mathrm{NaOH}$ ) which would have negated biochar-pH effects. However, in the nonbuffered dehydrogenase assay, the differential effect of straw versus pine wood biochars on the $\mathrm{pH}$ of both soils (Table 1) may have additionally influenced the behaviour of the dehydrogenase substrate (INT) in biochar-amended soil.

The relationship between substrate/product concentration and biochar concentration varied with respect to soil type (for pNPP, INT, and INTF), biochar type (for INT and INTF), or soil and biochar types (for pNP and INTF), as evidenced by significant two- and three-way interaction terms in the general linear model (Table 2). Biochar sorption of organics has previously been shown to be dependent on sorbate chemical properties and biochar feedstock [10]. pNPP and pNP (in predominantly phenolate form at the alkaline $\mathrm{pH}$ of the assay extraction), as negatively-charged molecules with low hydrophobicity $\left(\log K_{\mathrm{ow}} 0.87\right.$ and 1.91, resp.), might be expected not to sorb to biochar due to repulsion between the $\mathrm{pNPP} / \mathrm{pNP}$ anions and the negatively charged biochar functional groups. However, it has recently been suggested that aromatic organic acid anions adsorb to biochar via proton exchange with water and subsequent $\mathrm{H}$-bonding with carboxylate or phenolate biochar surface groups [11] and it is possible that this mechanism contributed to the sorption 


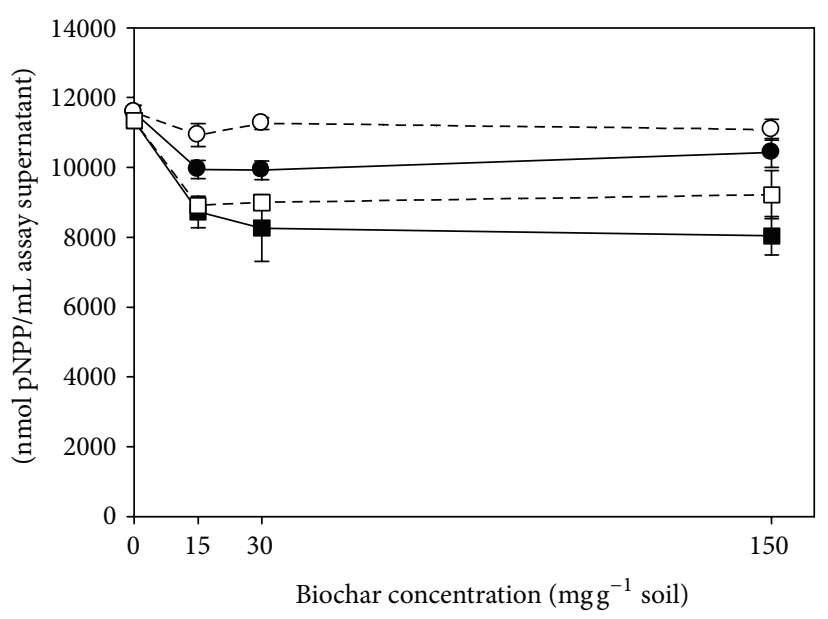

(a) p-Nitrophenyl phosphate

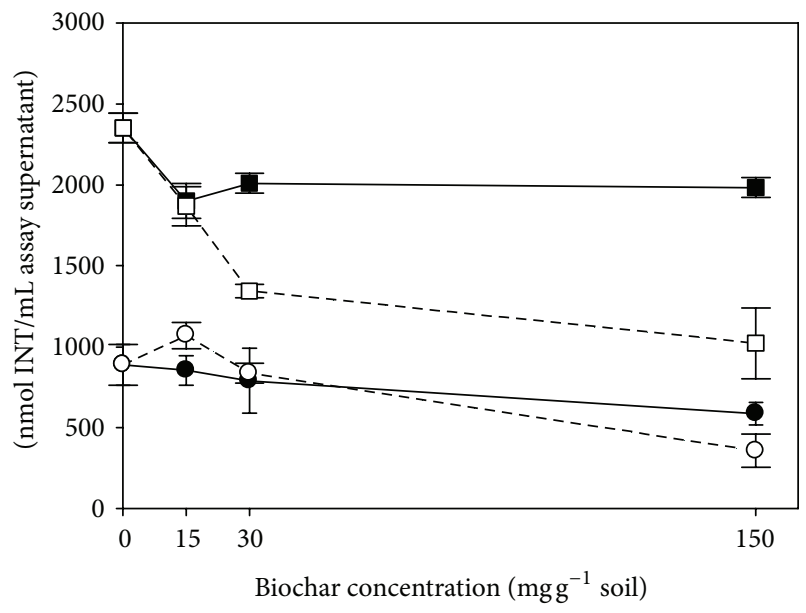

(c) Iodonitrotetrazolium chloride

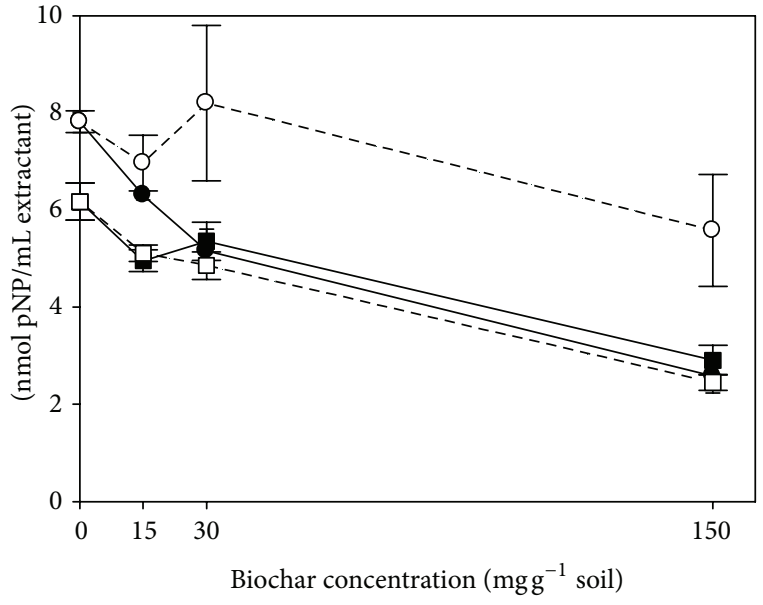

(b) p-Nitrophenol

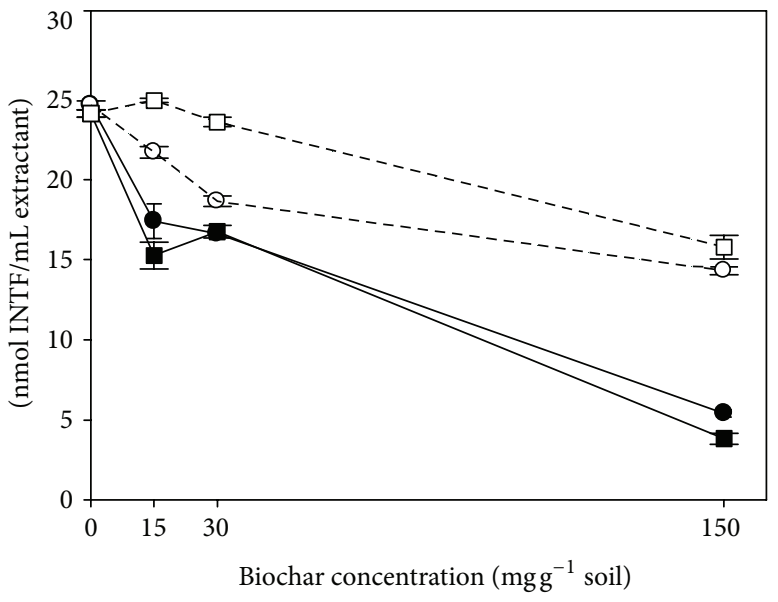

(d) Iodonitrotetrazolium formazan

FiguRE 2: Effect of biochar concentration $\left(0,15,30\right.$, or $150 \mathrm{mg}$ biochar $\mathrm{g}^{-1}$ soil) and biochar feedstock (straw or pine wood shavings) on the mean assay concentration or extractable concentration of enzyme assay substrates ( $a, c)$ and products (b, d), respectively, for dehydrogenase $(\mathrm{a}, \mathrm{b})$ and phosphatase $(\mathrm{c}, \mathrm{d})$ assays as applied to two different soils (Kettering or Cameroon sandy silt loams). Closed circle $=$ straw biochar, Kettering soil; open circle = pine wood shavings biochar, Kettering soil; closed square = straw biochar, Cameroon soil; open square = pine wood shavings biochar, Cameroon soil. Bars represent SEM $(n=4)$.

of pNP recorded here. By contrast to the anionic pNP and pNPP, INT is cationic and its sorption might be dominated by the cation exchange properties of the biochar-amended soils (Table 1; [12]); however, there was only weak evidence for a negative relationship between INT concentration and CEC for the pine wood biochar-amended soil $(P=0.13$, $\left.r^{2}=0.75\right)$. INTF, the dehydrogenase assay product, is a hydrophobic molecule $\left(\log K_{\mathrm{ow}}=6.91\right)$. Previous studies have suggested that hydrophobic organic chemicals sorb to biochar via a combination of partitioning to organic (noncarbonised) and adsorption to surface (carbonised) domains with surface adsorption becoming the dominant mechanism as pyrolysis temperature and time increase $[3,13]$. The pyrolysis conditions used here $\left(500^{\circ} \mathrm{C}, 1\right.$ hour $)$ probably resulted in biochars that retained a significant noncarbonised domain [3] and it is likely that INTF sorption was partially a function of partitioning to this phase. Whatever the mechanism of
INTF-biochar interaction, a proportion of the added INTF was clearly sorbed in a form that could not be recovered using the assay extractant, $\mathrm{N}, \mathrm{N}$-dimethylformamide : ethanol.

Overall, effects of biochar application on assay chemical behaviour were most pronounced for INTF in soils with the highest concentration of straw biochar $(\sim 80 \%$ of INTF nonextractable). However, sorption effects were still present at lower biochar concentrations that are more representative of agricultural field application rates [14] $\left(30 \mathrm{mg} \mathrm{g}^{-1}\right.$ is equivalent to 45 tonnes $\mathrm{ha}^{-1}$ assuming a depth of incorporation of $10 \mathrm{~cm}$ and a soil bulk density of $1.5 \mathrm{~g} \mathrm{~cm}^{-3}$ ). For example, for Cameroon soil receiving $30 \mathrm{mg} \mathrm{g}^{-1}$ biochar, reductions in concentrations were $43 \%$ (pine wood biochar) and 30\% (straw biochar) when compared to the nonamended control for INT and INTF, respectively.

Biochar sorption of assay constituents will impede the ability to assess genuine biochar effects on soil enzymes. 
Excessive sorption of the assay substrate could reduce its bioavailability to a concentration that is no longer saturating [5] which would result in an underestimation of potential activity and a reduction in the power of the assay to detect biochar treatment effects [15]. We recommend that the assumption of saturating substrate concentrations be checked in biochar-amended samples, and, if necessary, conditions optimised before commencing assays. As we have shown here for pNP and INTF, biochar can also significantly reduce the extractability of assay products which, if not corrected for, will also result in an underestimation of enzyme activities in biochar-amended soil. Incomplete extraction, attributed to sorption to organic matter, of pNP and INTF from high organic matter soils has been reported previously [16, 17] and, for INTF, matching the matrix of the calibration standards with that of the samples (i.e., including soil in the working standard solutions) has been recommended to account for matrix effects on product extractability [16]. Matrix-matched standards are more commonly applied for enzyme assays based on fluorogenic (4-methylumbelliferonelinked) substrates $[4,18]$. Based on the data presented here, we recommend that matrix-matched standards should be adopted for INT and also pNP-based assays when applied to biochar-amended soil.

\section{Acknowledgments}

The authors gratefully acknowledge Peter Harris, Ann Dudley, Kim Carter, and Alan Huscroft for their technical assistance.

\section{References}

[1] J. Lehmann, M. C. Rillig, J. Thies, C. A. Masiello, W. C. Hockaday, and D. Crowley, "Biochar effects on soil biota-a review," Soil Biology \& Biochemistry, vol. 43, no. 9, pp. 1812-1836, 2011.

[2] M. D. Wallenstein and M. N. Weintraub, "Emerging tools for measuring and modeling the in situ activity of soil extracellular enzymes," Soil Biology \& Biochemistry, vol. 40, no. 9, pp. 20982106, 2008.

[3] Z. Zhou, D. Shi, Y. Qiu, and G. D. Sheng, "Sorptive domains of pine chars as probed by benzene and nitrobenzene," Environmental Pollution, vol. 158, no. 1, pp. 201-206, 2010.

[4] Y. M. Awad, E. Blagodatskaya, Y. S. Ok, and Y. Kuzyakov, "Effects of polyacrylamide, biopolymer, and biochar on decomposition of soil organic matter and plant residues as determined by $14 \mathrm{C}$ and enzyme activities," European Journal of Soil Biology, vol. 48, pp. 1-10, 2012.

[5] V. L. Bailey, S. J. Fansler, J. L. Smith, and H. Bolton Jr., "Reconciling apparent variability in effects of biochar amendment on soil enzyme activities by assay optimization," Soil Biology \& Biochemistry, vol. 43, no. 2, pp. 296-301, 2011.

[6] J. Paz-Ferreiro, G. Gascó, B. Gutiérrez, and A. Méndez, "Soil biochemical activities and the geometric mean of enzyme activities after application of sewage sludge and sewage sludge biochar to soil," Biology and Fertility of Soils, vol. 48, pp. 511-517, 2012.

[7] M. A. Tabatabai and J. M. Bremner, "Use of p-nitrophenyl phosphate for assay of soil phosphatase activity," Soil Biology \& Biochemistry, vol. 1, no. 4, pp. 301-307, 1969.
[8] L. J. Shaw and R. G. Burns, "Enzyme activity profiles and soil quality," in Microbiological Methods For Assessing Soil Quality, J. Bloem, D. W. Hopkins, and A. Benedetti, Eds., CABI, 2005.

[9] W. von Mersi and F. Schinner, "An improved and accurate method for determining the dehydrogenase activity of soils with iodonitrotetrazolium chloride," Biology and Fertility of Soils, vol. 11, no. 3, pp. 216-220, 1991.

[10] S. M. Martin, R. S. Kookana, L. Van Zwieten, and E. Krull, "Marked changes in herbicide sorption-desorption upon ageing of biochars in soil," Journal of Hazardous Materials, vol. 231-232, pp. 70-78, 2012.

[11] J. Ni, J. J. Pignatello, and B. Xing, "Adsorption of aromatic carboxylate ions to black carbon (Biochar) is accompanied by proton exchange with water," Environmental Science \& Technology, vol. 45, no. 21, pp. 9240-9248, 2011.

[12] G. Merlin, T. Lissolo, V. Morel, D. Rossel, and J. Tarradellas, "Precautions for routine use of int-reductase activity for measuring biological-activities in soil and sediments," Environmental Toxicology and Water Quality, vol. 10, no. 3, pp. 185-192, 1995.

[13] B. Chen, D. Zhou, and L. Zhu, "Transitional adsorption and partition of nonpolar and polar aromatic contaminants by biochars of pine needles with different pyrolytic temperatures," Environmental Science \& Technology, vol. 42, no. 14, pp. 5137-5143, 2008.

[14] S. Jeffery, F. G. A. Verheijen, M. van der Velde, and A. C. Bastos, "A quantitative review of the effects of biochar application to soils on crop productivity using meta-analysis," Agriculture, Ecosystems \& Environment, vol. 144, no. 1, pp. 175-187, 2011.

[15] D. P. German, M. N. Weintraub, A. S. Grandy, C. L. Lauber, Z. L. Rinkes, and S. D. Allison, "Optimization of hydrolytic and oxidative enzyme methods for ecosystem studies," Soil Biology \& Biochemistry, vol. 43, no. 7, pp. 1387-1397, 2011.

[16] F. Camiña, C. Trasar-Cepeda, F. Gil-Sotres, and C. Leirós, "Measurement of dehydrogenase activity in acid soils rich in organic matter," Soil Biology \& Biochemistry, vol. 30, no. 8-9, pp. 10051011, 1998.

[17] A. F. Harrison, "Variation of four phosphorus properties in woodland soils," Soil Biology \& Biochemistry, vol. 11, no. 4, pp. 393-403, 1979.

[18] M.-C. Marx, M. Wood, and S. C. Jarvis, "A microplate fluorimetric assay for the study of enzyme diversity in soils," Soil Biology \& Biochemistry, vol. 33, no. 12-13, pp. 1633-1640, 2001. 

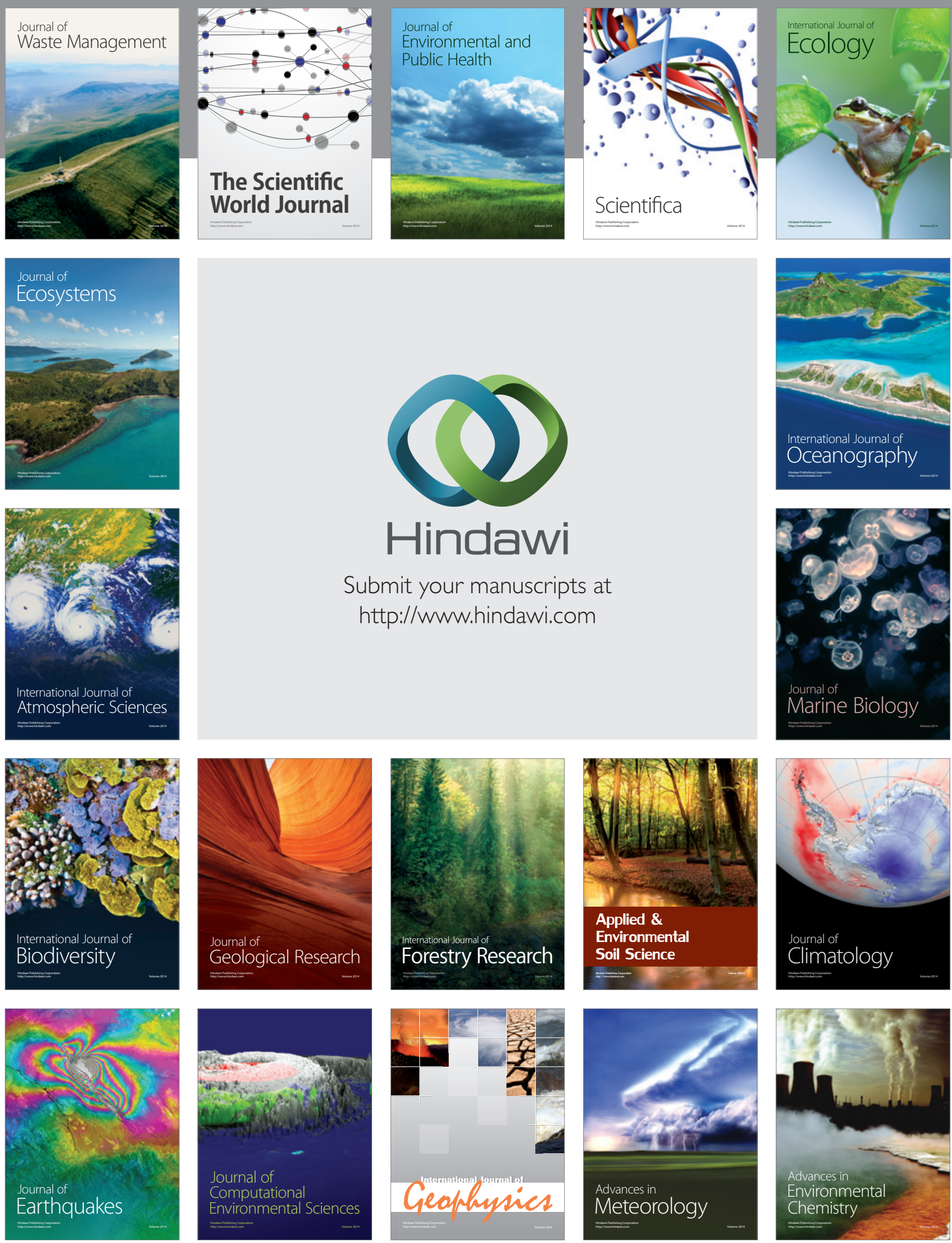